\title{
ANALISIS YURIDIS PENGGUNAAN BOM DALAM PENANGKAPAN IKAN DI WILAYAH PERAIRAN LAUT PULAU SEBUKU \\ KABUPATEN LAMPUNG SELATAN \\ (Studi Putusan Nomor : 321/Pid.Sus/2021/Pn.Tjk)
}

\section{JURIDICAL ANALYSIS OF THE USE OF BOMB IN FISHING \\ IN THE SEA WATER AREA OF SEBUKU ISLAND \\ SELATAN LAMPUNG DISTRICT \\ (Study of Decision Number : 321/Pid.Sus/2021/Pn.Tjk)}

\author{
Bella Cahya Ningrum ${ }^{1}$,I Ketut Siregig ${ }^{2}$, Suta Ramadan ${ }^{3}$ \\ Universitas Bandar Lampung \\ J1. ZA Pagar Alam No 26, Labuhan Ratu, Kecamatan Labuhan Ratu, Kota \\ Bandar Lampung \\ Email : bella.18211086@ student.ubl.ac.id
}

$\begin{array}{ll}\text { Submission } & : \text { 17 Januari } 2022 \\ \text { Accepted } & : \text { 25 Januari } 2022 \\ \text { Publish } & : \text { 31 Januari } 2022\end{array}$

\begin{abstract}
The illegal act of fishing with explosives is currently regulated by Law No. 45 of 2009 on Fisheries, which states several legal provisions, including that waters are under the sovereignty and jurisdiction of the Unitary State of the Republic of Indonesia, as well as the Indonesian Exclusive Economic Zone, and are based on international provisions containing fish resources and potential fish farming land. In this work, a normative juridical approach and an empirical approach were used as research methods. Data is gathered through library research and field studies. The Defendant employed explosives in the shape of 6 (six) big bottles and 4 (four) tiny bottles obtained by purchasing 4 (four) kilograms of Ampo powder and then assembling them in a way that they could be used to bomb fish in order to carry out his action. The imposition of a crime in this case has the goal of not only punishing people who commit crimes, but also of fostering and educating people, so the judge believes that the sentence imposed on the defendant was appropriate and commensurate with his actions, based on aggravating and mitigating circumstances.
\end{abstract}

Keywords: bomb using, fish catching.

\footnotetext{
Abstrak

Penangkapan ikan secara ilegal dengan bahan peledak saat ini diatur dalam UndangUndang Nomor 45 Tahun 2009 tentang Perikanan, yang menyatakan beberapa ketentuan hukum, di antaranya perairan berada di bawah kedaulatan dan yurisdiksi Negara Kesatuan Republik Indonesia, serta Negara Kesatuan Republik Indonesia. Zona Ekonomi
} 
Eksklusif, dan berdasarkan ketentuan internasional yang memuat sumber daya ikan dan potensi lahan pembudidayaan ikan. Dalam penelitian ini digunakan pendekatan yuridis normatif dan pendekatan empiris sebagai metode penelitian. Data dikumpulkan melalui penelitian kepustakaan dan studi lapangan. Terdakwa menggunakan bahan peledak berupa 6 (enam) botol besar dan 4 (empat) botol kecil diperoleh dengan membeli 4 (empat) kilogram bubuk Ampo kemudian dirangkai sedemikian rupa sehingga dapat digunakan untuk mengebom ikan guna melaksanakan aksinya. Penjatuhan pidana dalam hal ini bertujuan bukan hanya untuk menghukum orang yang melakukan tindak pidana, tetapi juga membina dan mendidik orang, sehingga hakim berpendapat bahwa pidana yang dijatuhkan kepada terdakwa sudah tepat dan setimpal dengan perbuatannya, berdasarkan pada hal-hal yang memberatkan dan keadaan yang meringankan.

Kata Kunci: penggunaan bom, penangkapan ikan.

\section{A. Pendahuluan}

Dalam UUD 1945 Pasal 1 ayat tiga berbunyi "Negara Indonesia adalah negara hukum”. Artinya, segala sesuatu yang berkaitan dengan keberadaan masyarakat, negara dan bangsa diatur sesuai dengan peraturan perundangundangan yang relevan. Misalnya, kebijakan pengunjung situs di jalur ganda diatur melalui kebijakan pengunjung situs. UUD 1945 Pasal 27 ayat 1 yang menyatakan "Semua penduduk mempunyai kedudukan yang sama dalam pengaturan dan kewenangan serta wajib menjunjung peraturan dan wewenang tersebut serta tidak menggunakan pengecualian”. Cara ini bahwa setiap warga negara di dalam wilayah Negara Kesatuan Republik Indonesia mempunyai kedudukan yang sama di bawah peraturan. Siapapun yang melanggar peraturan tersebut dapat dikenakan sanksi.

Indonesia adalah negara pedesaan yang sangat kaya akan sumberdaya alam yang sejak ratusan tahun yang lalu, tanah ini telah menjadi tempat liburan migrasi banyak orang negara untuk mencari kemakmuran. Orang-orang di tanah Hindia, dataran Indocina. Mereka semua bermimpi untuk kembali ke Indonesia. Mereka membangun perahu untuk sampai ke tanah dalam mimpi mereka khususnya tanah kelahiran Indonesia. Tatanan kehidupan dalam masyarakat sebenarnya tidak hanya dapat diartikan sebagai suatu cara untuk menyampaikan ketertiban kehidupan masyarakat, tetapi juga sebagai cara untuk mengekstradisi sikap dan gaya perilaku penduduk.

Pengaturan dan pengolahan sumber daya alam, terutama air, dirasakan semakin rumit dalam teknologi otonomi daerah dan memiliki kemampuan untuk 
memicu konflik antar daerah mandiri jika tidak lagi dipahami secara komprehensif atau menyeluruh. Secara ekonomi, tidak ada tempat yang tidak bias tanpa kerjasama dan interaksi dengan berbagai daerah. Keterkaitan antar daerah, masing-masing secara ekonomi dan ekologis, menunjukkan adanya perbedaan dalam sifat dan kemampuan aset yang dimiliki melalui sarana di setiap tempat, oleh karena itu pengolahan produk herbal di seluruh kabupaten/kota harus sepenuhnya berbasis pada komoditas herbal. akibat disparitas aset herbal. Pemahaman tentang disparitas aset kemampuan dapat dijadikan sebagai pemikiran untuk membangun kerjasama lintas kabupaten/kota yang bermanfaat bersama antar daerah. ${ }^{1}$

Laut adalah sesuatu yang unik, beberapa hal ini saling berhubungan tanpa mungkin ada penghalang. Indonesia diberkati dengan kekayaan herbal yang bermanfaat. Di perairan Negara Kesatuan Republik Indonesia terdapat sembilan (sembilan) wilayah pengendalian perikanan atau disingkat WPP. Ini meliputi Selat Malaka, Laut Cina Selatan dan Laut Natuna, Laut Jawa dan Selat Sunda, Selat Makassar dan Laut Flores, Laut Banda, Teluk Tomini dan Laut Maluku, Laut Sulawesi dan Samudera Pasifik, Laut Arafura, Samudera Hindia.

Indonesia sebagai daerah tropis, memiliki keanekaragaman hayati yang tepat di darat dan di laut yang tinggi, khususnya di daerah pesisir, Keanekaragaman hayati tidak terlepas dari situasi geofisika dan letak geografis perairan Indonesia. Sebagaimana diketahui bahwa Indonesia adalah salah satu dari Amerika Serikat kepulauan terbesar di dunia, dengan 17.508 pulau yang terbentang sepanjang khatulistiwa dan $1.760 \mathrm{~km}$ dari utara ke selatan. Tanah sekitar Amerika Serikat Indonesia mencapai 1.sembilan km2 dan sekitar perairan laut tercatat sekitar 7.sembilan km2. Lagi Selanjutnya Negara Indonesia memiliki garis pantai kurang lebih $81.791 \mathrm{~km}$, yang adalah pantai terpanjang kedua di dunia, setelah Kanada. Panjang Perairan dangkal ini berkembang dan kisaran organismenya tinggi penghuni. Organisme ini tersebar di seluruh sub-struktur di

\footnotetext{
${ }^{1}$ Marpaung, Lintje. Anna., Hartono, Bambang., Rusli, Tami., Erlina, B., \& Pane, Erina, 2008, Kebijakan Pengelolahan Sumbedaya Air dalam Hubungannya dengan Otonomi Daerah (Studi di propinsi Lampung), Jurnal Pranata Hukum, Vol.3, No.2, hlm.1
} 
dalam ekosistem perairan pesisir laut tropis, selain itu ekosistem tersebut juga diakui memiliki kapasitas yang cukup besar untuk memandu produksi perikanan. ${ }^{2}$

Dalam konteks hukum Indonesia, tindak pidana penangkapan ikan dengan bahan peledak saat ini diatur melalui sarana Undang-undang Nomor empat puluh lima tahun 2009 tentang Perikanan yang menyatakan berbagai ketentuan pidana, khususnya perairan yang berada di bawah kedaulatan dan yurisdiksi Negara Kesatuan Republik Indonesia dan Zona Ekonomi Eksklusif Indonesia dan terutama didasarkan sepenuhnya pada pedoman dunia yang menggabungkan aset perikanan dan kemampuan lahan budidaya ikan, adalah keuntungan dari Tuhan Yang Maha Esa. Diamanatkan kepada bangsa Indonesia terutama berdasarkan sepenuhnya pada UUD 1945, untuk diterapkan sebesar-besarnya bagi kesejahteraan dan kemakmuran umat manusia Indonesia.

Berdasarkan Undang-Undang Nomor 31 Tahun 2004 tentang Perikanan dan Undang-Undang Nomor empat puluh lima Tahun 2009 tentang Perubahan atas Undang-Undang Nomor 31 Tahun 2004 tentang Perikanan, dikenal berbagai macam tindak pidana perikanan yang diatur dalam Pasal 86 sampai dengan 101. Tindak pidana perikanan terbagi atas, tindak pidana pencemaran, perusakan kekayaan ikan dan penangkapan ikan penggunaan bahan peledak, tindak pidana pengelolaan kekayaan ikan, dan tindak pidana pengusahaan perikanan tanpa izin. ${ }^{3}$

Regulasi Indonesia memiliki semangat yang luar biasa dalam memberantas penangkapan ikan dengan bahan peledak dengan upaya DPR membuat UU Perikanan, namun dalam implementasinya UU tersebut kini sudah tidak mampu lagi berjalan Sesuai dengan keinginan masyarakat pecinta regulasi di Indonesia, termasuk kasus yang terjadi di perairan laut Pulau Sebuku, Kabupaten Lampung Selatan sekiranya pada bulan maret 2021, telah terjadi perbuatan tindak pidana menggunakan bom untuk menangkap ikan. Dalam hal itu Petugas Direktorat Kepolisian Perairan (Ditpolair) Polda Lampung menangkap Deli Bin Kelata hlm. 10

${ }^{2}$ Supriadi dan Alimudin, 2001, Hukum Perikanan di Indonesia, Sinar Grafika, Jakarta,

${ }^{3}$ Haryono Somun, 2014, Tinjauan Kriminologis Penggunaan Bahan Peledak Dalam Penangkapan Ikan Di Desa Kalupapi Kecamatan Bangkurung Kabupaten Bangkep, Jurnal Ilmu Hukum Legal Opinion, Ed. 3, Vol. 2, hlm. 8 
(Alm), karena melakukan pengeboman ikan di Perairan Pulau Sebuku, Lampung Selatan. Dari penangkapan pelaku, petugas menyita barang bukti berupa :

a. 6 (enam) Botol Besar yang berisis Bahan Peledak jenis Bom Ikan

b. 10 (Sepuluh) Botol Sedang yang berisi Bahan Peledak jenis Bom Ikan

c. 1 (satu) kg Serbuk Ampo warna Putih

d. 1 (satu) buah plastik berisi $\pm 1 \mathrm{~kg}$ belerang yang sudah dicampur Cat Bron

e. 10 (sepuluh) buah Sumbu Ledak / Detonator

f. 5 (lima) buah potongan Karet Sendal

g. 13 (Tiga Belas) Buah Korek Api

h. 2 (dua) buah Potongan Sikat Gigi

i. 1 (satu) buah Ember Warna Putih

j. 1 (satu) Unit Kapal warna Merah Lis Putih bermesin Dompeng

k. 1 (satu) Unit Sampan/Perahu Dayung

1. 1(satu) Unit Kompresor Merk SWAN warna Hijau berikut selang Kompresor warna Kuning

m. 2 (dua) buah Box Fiber warna Kuning dan Merah

Barang bukti tersebut adalah bahan dan alat yang digunakan pelaku dalam melaksanakan aksi illegalnya. Sebelumnya ada laporan bahwa di perairan Pulau Sebuku selama ini masih sering terjadi suara ledakan yang diduga nelayan sedang melakukan penangkapan ikan menggunakan bahan peledak (bom ikan) kemudian dibekuk polisi berkat adanya laporan masyarakat tentang aktivitas mencari ikan dengan bom di perairan Pulau Sebuku.

Berdasarkan uraian latar belakang di atas, penulis akan melaksanakan penelitian untuk melihat yang di tuangkan dalam rangka penyusunan artikel ini dengan judul: “Analisis Yuridis Penggunaan Bom Dalam Penangkapan Ikan Di Wilayah Perairan Laut Pulau Sebuku Kabupaten Lampung Selatan (Studi Putusan Nomor : 321/Pid.Sus/2021/Pn.Tjk)".

Berdasarkan uraian latar belakang diatas, permasalahan yang akan diambil dalam penulisan artikel ini adalah : 
a. Bagaimana cara pelaku menggunakan bom ikan di wilayah Perairan Laut Pulau Sebuku Kabupaten Lampung Selatan?

b. Bagaimanakah pertimbangan hakim dalam menjatuhkan pidana terhadap pelaku penggunaan bom dalam penangkapan ikan?

Metode penelitian yang digunakan dalam penelitian ini ialah pendekatan yuridis normatif dan pendekatan empiris. Pengumpulan data berdasarkan studi kepustakaan dan studi lapangan, sedangkan pengolahan data dilakukan metode editing, klasifikasi dan sistemasi data. Narasumber dalam penelitian ini meliputi penyidik ditpolairut Polda Lampung, Penuntut Umum, Hakim.

\section{B. Hasil Penelitian dan Pembahasan}

\section{Cara Pelaku Menggunakan Bom Ikan Di Wilayah Perairan Laut Pulau Sebuku Kabupaten Lampung Selatan.}

Pengeboman ikan adalah malpraktek dalam menangkap ikan atau menggunakan sumber perikanan yang secara hukum bertentangan dengan peraturan. Semua putusan pengadilan harus mencakup motif dan alasan keputusan, juga harus mencakup pasal-pasal tertentu dari peraturan yang berlaku atau pengaturan ulang tidak tertulis dari peraturan yang dapat digunakan sebagai dasar untuk mengadili.

Penggunaan bahan kimia, zat organik, bahan peledak, peralatan dan/atau metode, dan/atau rumah yang dapat merusak dan/atau membahayakan perlindungan sumber daya ikan dan sekitarnya yang kini tidak lagi hanya membunuh ikan secara langsung, tetapi juga dapat membahayakan kesehatan manusia. dan merugikan nelayan dan pembudidaya ikan. Jika ada kerugian akibat penggunaan zat dan peralatan tersebut, akan memakan waktu lama untuk kembali ke keadaan aslinya, bahkan kemungkinan besar akan punah. ${ }^{4}$

Faktor penyebab pelaku melakukan kejahatan antara lain:

1. Faktor mental individu itu sendiri dapat melakukan kejahatan bersamasama dengan kekuatan emosional, mentalitas rendah, merugikan korban, balas dendam.

\footnotetext{
${ }^{4}$ Suharto, 2011, Limbah Kimia dalam Pencemaran Udara dan Air Edisi Pertama, Andi Offset, Yogyakarta, hlm. 61
} 
2. Faktor kurangnya kesadaran masyarakat juga menjadi penyebab kejahatan ujaran kebencian, khususnya hinaan yang dilakukan di media sosial. Minimnya sosialisasi/penyuluhan kepada jaringan inilah yang menjadi penyebab munculnya kejahatan ini pada orang-orang yang dikategorikan sudah tidak lagi mengetahui kehidupan regulasi tentang kejahatan ujaran kebencian, khususnya penghinaan.

3. Faktor sarana dan prasarana juga berdampak pada teknologi globalisasi seperti sekarang ini, dan juga berdampak pada pesatnya perkembangan media digital, khususnya media internet agar penyebaran data lebih mudah, lebih cepat dan lebih kuat untuk diperoleh. Sehingga seseorang tidak selalu cukup bijaksana untuk menggunakan internet atau pusat media percakapan dan tidak ada batasan dalam penggunaan alat percakapan. $^{5}$

Terdakwa dilimpahkan ke persidangan Kamis, Jaksa Penuntut Umum didakwa seluruhnya berdasarkan surat-surat yang pada pokoknya telah ditetapkan bahwa Terdakwa Deli Bin Kelata (alm), pada tanggal 14 Januari 2021 sekitar pukul 12.00 WIB, berlokasi di dalam Perairan Laut Pulau Sebuku Kabupaten Lampung Selatan pada koordinat (lima nol 52' 58” LS - 10 037' 17” BT), namun karena Tergugat dipindahkan di Polairud Lampung dan rumah tinggal maksimal yang dipanggil telah menghadap Pengadilan Negeri Tanjung Karang, maka berdasarkan seluruhnya berdasarkan Pasal delapan puluh empat ayat (2) KUHAP Pengadilan Negeri Tanjung Karang yang paling sederhana mengadili perkara ini "siapa yang melakukan, siapa yang menyuruh, siapa yang ikut serta dalam melakukan perpindahan tanpa hak untuk melukiskan ke Indonesia, membuat, menerima, mencoba, memperoleh, menyerahkan atau mencoba menyerahkan, menguasai, membawa, Dalam kepemilikannya atau dalam kepemilikannya, Buang, Transportasi, Sembunyikan, Gunakan atau Hapus dari Indonesia Semua Senjata Api, Amunisi, atau Bahan Peledak Apa Pun.

${ }^{5}$ M. Choirul Anam dan Muhammad Hafiz, 2015, Penanganan Ujaran Kebencian (Hate Speech) dalam Kerangka Hak Asasi Manusia, Remadja Karya, Bandung, hlm. 10 
Terdakwa melakukan pengeboman ikan dengan cara sebagai berikut:

Berawal pada hari Rabu Tanggal 13 Januari 2021, Tim Petugas kepolisian Polairud Lampung mendapatkan informasi bahwa di perairan laut Pulau Sebuku ada penggunaan Bahan Peledak. Selanjutnya pada Hari Kamis 14 Januari 2021 sekitar jam 12.00 wib Tim Petugas kepolisian Polairud Lampung yaitu saksi ARIANSYAH Bin LABRONI dan saksi JOKO SUPRIADI Bin AMANI di Perairan Laut Pulau Sebukunkecil Kabupaten Lampung Selatan, Tim melakukan penangkapan terhadap Terdakwa DELI Bin KELATA Bersama-sama DAPIT BIN DELI dan DANIEL GEOVANI Bin yang berada di Kapal warna Merah Lis Putih bermesin Dompeng. Selanjutnya pada saat pemeriksaan diketemukan barang bukti berupa 6 (enam) Botol Besar yang berisis Bahan Peledak jenis Bom Ikan, 10 (Sepuluh) Botol Sedang yang berisi Bahan Peledak jenis Bom Ikan, 1 (satu) kg Serbuk Ampo warna Putih, 1 (satu) buah plastik berisi $\pm 1 \mathrm{~kg}$ belerang yang sudah dicampur Cat Bron, 10 (sepuluh) buah Sumbu Ledak / Detonator, 5 (lima) buah potongan Karet Sendal, 13 (Tiga Belas) Buah Korek Api, 2 (dua) buah Potongan Sikat Gigi, 1 (satu) buah Ember Warna Putih. 1 (satu) Unit Kapal warna Merah Lis Putih bermesin Dompeng, 1 (satu) Unit Sampan/Perahu Dayung, 1(satu) Unit Kompresor Merk SWAN warna Hijau berikut selang Kompresor warna Kuning, 2 (dua) buah Box Fiber warna Kuning dan Merah.

Selanjutnya pada saat pemeriksaan Terdakwa DELI Bin KELATA menerangkan bahwa bahan peledak tersebut miliknya. Kemudian Terdakwa menerangkan bahwa bahan peledak berupa 6 (enam) botol besar dan 4 (empat) buah botol kecil didapat dengan cara membeli sebanyak 4 (empat) kilogram bubuk Ampo sekitar 2 Tahun yang lalu dari UDIN di Jalan Daerah Sinar Laut Teluk betung dan saat ini tidak diketahui keberadaannya. Selanjutnya Terdakwa merakit Bahan peledak tersebut dengan cara bubuk ampo diaduk beserta solar dan cat besi, setelah tercampur dimasukan kedalam 10 (sepuluh) botol besar dan 4 (empat) botol kecil hingga penuh, selanjutnya membuat detonator dengan 11 (sebelas) sedotan kecil yang di isi dengan serbuk di kepala korek api. Selanjutya detonator tersebut dimasukan kedalam botol yang telah di isi dengan bahan peledak. Kemudian setelah botol yang berisi bahan peledak tadi siap digunakan, 
Terdakwa mengajak DAPIT BIN DELI untuk mempergunakan botol peledak tersebut untuk mencari ikan. Kemudian DELI Bin KELATA meminta DAPIT BIN DELI untuk menjemput DANIEL GEOVANI Bin MAWARDI untuk bersama-sama menggunakan botol yang berisi bahan peledak untuk digunakan mencari ikan di laut.

Selanjutnya DAPIT BIN DELI bertugas menghidupkan mesin Kapal dan memegang kemudi sedangkan DANIEL GEOVANI Bin MAWARDI bertugas menarik jangkar dan menguras air di dalam kapal dan DELI Bin KELATA (Alm) bertugas mengambil ikan.

Kemudian DAPIT BIN DELI dan DANIEL GEOVANI Bin MAWARDI bersama DELI Bin KELATA pada hari Rabu tanggal 13 Januari 2021 menuju perairan Sebuku sekitar jam 06.00 wib sambil membawa perahu sampan yang di ikat dengan tali di belakang kapal. Kemudian sekitar jam 16.00 wib DELI Bin KELATA meminta DAPIT BIN DELI untuk lego jangkar untuk istirahat sebentar, kemudian DELI Bin KELATA mengeluarkan 1 (satu) botol kecil yang berisi bahan peledak yang digunakan untuk mendapatkan ikan. Selanjutnya ikan yang didapat dari hasil tersebut dimasak lalu dimakan bersama. Setelah itu DAPIT BIN DELI dan DANIEL GEOVANI Bin MAWARDI bersama DELI menginap di Pulau Sebuku. Keesokan harinya sekitar Jam 11.00 wib kapal kembali bertolak ke Pulau Sebuku Kecil dan sekitar jam 12.00 wib DELI Bin KELATA menyuruh DANIEL GEOVANI Bin MAWARDi untuk membuang jangkar agar kapal berhenti dan DELI Bin KELATA turun menggunakan sampan ke daratan pulau untuk mengambil dugan/ kelapa muda, kemudian datang Petugas kepolisian Polairud Lampung melakukan pengkapan, selanjutnya Terdakwa bersama DAPIT BIN DELI dan DANIEL GEOVANI Bin MAWARDI beserta barang bukti di bawa ke Kantor Polairud guna pemeriksaan lebih lanjut.

Berdasarkan Hasil Berita Acara Pemeriksaan Laboratorium Forensik Nomor Lab : 09/BHF/2021 Tanggal 04 Februari 2021, yang ditandatangani oleh yang ditandatangani oleh EDHI SURYANTO S.Si., Apt, M.M.,M.T dkk dengan kesimpulan : a. Barang bukti seperti tersebut pada bab I butir I diatas, merupakan sumbu peledak yang didlamnya mengandung campuran bahan peledak jenis Low 
Explosive Dan High Explosive dengan senyawa bahan peledak yaitu campuran Potassium ( K ), Klorap (C1O3) ) dan TNT ; b. Barang bukt seperti tersebut pada bab I butir 4 diatas, merupakan bongkahan warna putih yang mengandung unsur bahan peledak jenis Low Explosive yaitu campuran Potassium Potassium ( K) , Klorap (CIO3) ; c. Barang bukti seperti tersebut pada bab I butir 1 diatas , merupakan sumbu peledak yang didalamnya mengandung campuran bahan peledak jenis Low Explosive Dan High Explosive dengan senyawa bahan peledak yaitu campuran Potassium ( K), Klorap (C1O3) dan TNT.

Bahwa bahan peledak tersebut tidak berhubungan dengan pekerjaan Terdakwa. Dan terdakwa Tidak mendapat izin dari pihak yang berwenang dalam hal membuat, menguasai, membawa, memiliki persediaan atau memiliki, menyimpan, mengangkut, menyembunyikan, dan penggunaan bahan peledak. Pergerakan terdakwa sebagaimana diatur dan menimbulkan akibat yang merugikan dalam Pasal 1 Ayat (1) UU Darurat No. 12 Tahun 1951 tentang Bahan Peledak atau Senjata Api Jo. Pasal lima puluh lima Ayat (1) KUHP.

\section{Pertimbangan Hakim Dalam Menjatuhkan Pidana Terhadap Pelaku Penggunaan Bom Dalam Penangkapan Ikan}

Dalam menganalisis suatu kasus, hakim perlu mengetahui bukti-bukti, karena akibat dari pembuktian tersebut nantinya akan digunakan sebagai bahan perhatian untuk menentukan kasus. Bukti adalah tingkat yang sangat penting dalam ujian di persidangan. Penyebab pembuktian adalah untuk mencapai kebenaran bahwa suatu peristiwa/kenyataan yang dikemukakan ini pasti terjadi, sehingga seseorang dapat mencapai pilihan pilihan yang nyata dan benar. Pilihan tersebut kini tidak lagi dapat melewati sebuah pilihan sebelum itu jelas baginya bahwa peristiwa/kenyataan itu pasti terjadi, ini sudah teruji kebenarannya, sehingga seolah-olah ada pengadilan pidana di antara para pihak. ${ }^{6}$

Ketentuan hukum yang terus-menerus tertinggal dari keinginan dan sifat masyarakat mengharuskan hakim untuk melakukan pemeriksaan pidana yang lengkap yang dikenal dengan interpretasi pidana. Berdasarkan asas Ahmad Rifai,

\footnotetext{
${ }^{6}$ Rahmawati, D., Siregig, I. K., \& Hasan, Z, 2021, Pertimbangan Hakim Dalam Menjatuhkan Pidana Terhadap Pelaku Tindak Pidana Pembunuhan Berencana, Widya Yuridika Jurnal Hukum, Vol.4, No.1, hlm.5
} 
konsep hakim dalam menguraikan peraturan perundang-undangan dapat dibagi menjadi 2 (dua) teori, terutama asas penemuan peraturan heteronom dan asas penemuan peraturan yang berdiri sendiri. Perbedaan sederhana antara kedua teori tersebut terletak pada besarnya kepastian hakim dengan menggunakan ketentuan pidana tertulis. Asas penemuan peraturan yang heterogen menempatkan hakim sebagai corong peraturan, sedangkan asas penemuan peraturan yang mandiri menempatkan hakim pada kebebasan untuk mengakui dan menghubungkan peraturan tersebut sesuai dengan kemajuan masyarakat. ${ }^{7}$

Teori penegakan hukum merupakan suatu usaha untuk mewujudkan ide-ide dan konsep-konsep menjadi kenyataan. Penegakan hukum adalah suatu proses untuk mewujudkan keinginan-keinginan hukum menjadi kenyataan. Yang disebut keinginan-keinginan hukum disini tidak lain adalah pikiran-pikiran pembuatan undang-undang yang dirumuskan dalam peraturan hukum itu. Pembicaraan mengenai proses penegakan hukum ini menjangkau pula sampai kepada pembuatan hukum. ${ }^{8}$

Majelis hakim menimbang, bahwa Terdakwa telah didakwa oleh Penuntut Umum dengan dakwaan tunggal sebagaimana diatur dalam Pasal 1 Ayat (1) Undang Undang Darurat No. 12 Tahun 1951 tentang Bahan Peledak atau Senjata Api Jo. Pasal 55 Ayat (1) KUHP, yang unsur-unsurnya adalah sebagai berikut :

1. Unsur Barang Siapa

2. Unsur tidak memiliki izin dari pihak yang berwenang dalam hal Membuat, Menguasai, Membawa, Mempunyai Persediaan Padanya atau Mempunyai Dalam Miliknya, Menyimpan, Mengangkut, Menyembunyikan, Mempergunakan Bahan Peledak ;

3. Unsur yang melakukan, yang menyuruh melakukan, yang turut serta melakukan perbuatan;

\footnotetext{
${ }^{7}$ Ahmad Rifai, 2010, Penemuan Hukum oleh Hakim dalam Perspektif Hukum Progresif, Sinar Grafika, Jakarta, hlm. 19

${ }^{8}$ Zainab Ompu Jainah, 2012, Penegakan Hukum Dalam Masyarakat, Journal Of Rural And Development, Vol. 3, No. 2, hlm.1
} 
Terhadap unsur-unsur tersebut Majelis Hakim mempertimbangkan sebagai berikut:

Unsur Barang Siapa; bahwa yang dimaksud dengan unsur barang siapa adalah siapa saja yaitu manusia sebagai subjek hukum yang dapat mempertanggungjawabkan perbuatan yang telah dilakukanya dan didalam diri manusia tersebut tidak ditemukan alasan penghapus pidana (Strafuitsluitingsgronden) baik berupa alasan yang dapat menghilangkan sifat melawan hukum atas adanya sesuatu perbuatan yang telah dilakukanya (rechtvaardigingsgronden) ataupun alasan peniadaan kesalahan (schulduitsluitingsgronden). Dan hal ini apabila kita hubungkan dengan fakta yang terungkap di depan persidangan dimana di dalam diri terdakwa tidak ditemukanya alasan penghapus pidana pada saat perbuatan dilakukan dan terdakwa dapat menjawab pertanyaan yang diajukan dipersidangan, dan berdasarkan keterangan para saksi dan terdakwa di depan persidangan bahwa yang menjadi terdakwa dalam perkara ini adalah terdakwa DELI Bin KELATA (Alm) sesuai surat dakwaan, dimana sesuai fakta di persidangan terdakwa dalam keadaan sehat jasmani dan rohani, tidak ditemui adanya alasan pemaaf dan pembenar pada diri terdakwa, sehingga terdakwa dapat mempertanggungjawabkan perbuatannya. Menimbang, bahwa berdasarkan pertimbangan tersebut diatas, Majelis berkesimpulan unsur ini telah terpenuhi.

Unsur tidak memiliki izin dari pihak yang berwenang dalam hal Membuat, Menguasai, Membawa, Mempunyai Persediaan Padanya atau Mempunyai Dalam Miliknya, Menyimpan, Mengangkut, Menyembunyikan, Mempergunakan Bahan Peledak.

Berdasarkan fakta-fakta dipersidangan dari keterangan para saksi, ahli, terdakwa sendiri dan Barang Bukti bahwa Berawal pada hari Rabu Tanggal 13 Januari 2021, Tim Petugas kepolisian Polairud Lampung mendapatkan informasi bahwa di perairan laut Pulau Sebuku ada penggunaan Bahan Peledak. Selanjutnya pada Hari Kamis 14 Januari 2021 sekitar jam 12.00 wib Tim Petugas kepolisian Polairud Lampung yaitu saksi ARIANSYAH BinLABRONI dan saksi JOKO SUPRIADI Bin AMANI di Perairan Laut Pulau Sebukunkecil Kabupaten 
Lampung Selatan, Tim melakukan penangkapan terhadap Terdakwa DELI Bin KELATA Bersama-sama DAPIT BIN DELI dan DANIEL GEOVANI Bin MAWARDI (dilakukan pemeriksaan dalam berkas perkara terpisah) yang berada di Kapal warna Merah Lis Putih bermesin Dompeng. Selanjutnya pada saat pemeriksaan diketemukan barang bukti berupa 6 (enam) Botol Besar yang berisis Bahan Peledak jenis Bom Ikan, 10 (Sepuluh) Botol Sedang yang berisi Bahan Peledak jenis Bom Ikan, 1 (satu) kg Serbuk Ampo warna Putih, 1 (satu) buah plastik berisi $\pm 1 \mathrm{~kg}$ belerang yang sudah dicampur Cat Bron, 10 (sepuluh) buah Sumbu Ledak / Detonator, 5 (lima) buah potongan Karet Sendal, 13 (Tiga Belas) Buah Korek Api, 2 (dua) buah Potongan Sikat Gigi, 1 (satu) buah Ember Warna Putih. 1 (satu) Unit Kapal warna Merah Lis Putih bermesin Dompeng, 1 (satu) Unit Sampan/Perahu Dayung, 1(satu) Unit Kompresor Merk SWAN warna Hijau berikut selang Kompresor warna Kuning, 2 (dua) buah Box Fiber warna Kuning dan Merah. Selanjutnya DAPIT BIN DELI dan DANIEL GEOVANI Bin MAWARDI bersama DELI Bin KELATA pada hari Rabu tanggal 13 Januari 2021 menuju perairan Sebuku sekitar jam 06.00 wib sambil membawa perahu sampan yang di ikat dengan tali di belakang kapal. Kemudian sekitar jam 16.00 wib DELI Bin KELATA meminta DAPIT BIN DELI untuk lego jangkar untuk istirahat sebentar, kemudian DELI Bin KELATA mengeluarkan 1 (satu) botol kecil yang berisi bahan peledak yang digunakan untuk mendapatkan ikan. Selanjutnya ikan yang didapat dari hasil tersebut dimasak lalu dimakan bersama. Setelah itu DAPIT BIN DELI dan DANIEL GEOVANI Bin MAWARDI bersama DELI menginap di Pulau Sebuku. Keesokan harinya sekitar Jam 11.00 wib kapal kembali bertolak ke Pulau Sebuku Kecil dan sekitar jam 12.00 wib DELI Bin KELATA menyuruh DANIEL GEOVANI Bin MAWARDI untuk membuang jangkar agar kapal berhenti dan DELI Bin KELATA turun menggunakan sampan ke daratan pulau untuk mengambil dugan/ kelapa muda, kemudian datang Petugas kepolisian Polairud Lampung melakukan pengkapan, selanjutnya Terdakwa bersama DAPIT BIN DELI dan DANIEL GEOVANI Bin MAWARDI beserta barang bukti di bawa ke Kantor Polairud guna pemeriksaan lebih lanjut. Terdakwa DELI Bin KELATA menerangkan bahwa bahan peledak tersebut miliknya. 
Terdakwa mengajak DAPIT BIN DELI untuk mempergunakan botol peledak tersebut untuk mencari ikan. Kemudian DELI Bin KELATA meminta DAPIT BIN DELI untuk menjemput DANIEL GEOVANI Bin MAWARDI untuk bersama-sama menggunakan botol yang berisi bahan peledak untuk digunakan mencari ikan di laut. Selanjutnya DAPIT BIN DELI bertugas menghidupkan mesin Kapal dan memegang kemudi sedangkan DANIEL GEOVANI Bin MAWARDI bertugas menarik jangkar dan menguras air di dalam kapal dan DELI Bin KELATA (Alm) bertugas mengambil ikan.

Berdasarkan Hasil Berita Acara Pemeriksaan Laboratorium Forensik Nomor Lab : 09/BHF/2021 Tanggal 04 Februari 2021, yang ditandatangani oleh yang ditandatangani oleh EDHI SURYANTO S.Si., Apt, M.M.,M.T dkk dengan kesimpulan :

a. Barang bukti seperti tersebut pada bab I butir I diatas, merupakan sumbu peledak yang didlamnya mengandung campuran bahan peledak jenis Low Explosive Dan High Explosive dengan senyawa bahan peledak yaitu campuran Potassium ( K ), Klorap (C1O3) ) dan TNT ;

b. Barang bukt seperti tersebut pada bab I butir 4 diatas, merupakan bongkahan warna putih yang mengandung unsur bahan peledak jenis Low Explosive yaitu campuran Potassium Potassium ( K), Klorap (CIO3) ;

c. Barang bukti seperti tersebut pada bab I butir 1 diatas, merupakan sumbu peledak yang didalamnya mengandung campuran bahan peledak jenis Low Explosive Dan High Explosive dengan senyawa bahan peledak yaitu campuran Potassium ( $\mathrm{K}$ ), Klorap (C1O3) dan TNT. Bahwa berdasarkan pertimbangan tersebut diatas, Majelis berkesimpulan unsur ini telah terpenuhi.

Unsur yang melakukan, yang menyuruh melakukan, yang turut serta melakukan perbuatan; bahwa berdasarkan fakta-fakta dipersidangan dari keterangan para saksi, ahli, terdakwa sendiri dan Barang Bukti bahwa Berawal pada hari Rabu Tanggal 13 Januari 2021, Tim Petugas kepolisian Polairud Lampung mendapatkan informasi bahwa di perairan laut Pulau Sebuku ada penggunaan Bahan Peledak. Selanjutnya pada Hari Kamis 14 Januari 2021 sekitar jam 12.00 wib Tim Petugas kepolisian Polairud Lampung yaitu saksi 
ARIANSYAH BinLABRONI dan saksi JOKO SUPRIADI Bin AMANI di Perairan Laut Pulau Sebukunkecil Kabupaten Lampung Selatan, Tim melakukan penangkapan terhadap Terdakwa DELI Bin KELATA Bersama-sama DAPIT BIN DELI dan DANIEL GEOVANI Bin MAWARDI (dilakukan pemeriksaan dalam berkas perkara terpisah) yang berada di Kapal warna Merah Lis Putih bermesin Dompeng. Selanjutnya pada saat pemeriksaan diketemukan barang bukti berupa 6 (enam) Botol Besar yang berisis Bahan Peledak jenis Bom Ikan, 10 (Sepuluh) Botol Sedang yang berisi Bahan Peledak jenis Bom Ikan, 1 (satu) kg Serbuk Ampo warna Putih, 1 (satu) buah plastik berisi $\pm 1 \mathrm{~kg}$ belerang yang sudah dicampur Cat Bron, 10 (sepuluh) buah Sumbu Ledak / Detonator, 5 (lima) buah potongan Karet Sendal, 13 (Tiga Belas) Buah Korek Api, 2 (dua) buah Potongan Sikat Gigi, 1 (satu) buah Ember Warna Putih. 1 (satu) Unit Kapal warna Merah Lis Putih bermesin Dompeng, 1 (satu) Unit Sampan/Perahu Dayung, 1(satu) Unit Kompresor Merk SWAN warna Hijau berikut selang Kompresor warna Kuning, 2 (dua) buah Box Fiber warna Kuning dan Merah. Selanjutnya DAPIT BIN DELI dan DANIEL GEOVANI Bin MAWARDI bersama DELI Bin KELATA pada hari Rabu tanggal 13 Januari 2021 menuju perairan Sebuku sekitar jam 06.00 wib sambil membawa perahu sampan yang di ikat dengan tali di belakang kapal. Kemudian sekitar jam 16.00 wib DELI Bin KELATA meminta DAPIT BIN DELI untuk lego jangkar untuk istirahat sebentar, kemudian DELI Bin KELATA mengeluarkan 1 (satu) botol kecil yang berisi bahan peledak yang digunakan untuk mendapatkan ikan. Selanjutnya ikan yang didapat dari hasil tersebut dimasak lalu dimakan bersama. Setelah itu DAPIT BIN DELI dan DANIEL GEOVANI Bin MAWARDI bersama DELI menginap di Pulau Sebuku. Keesokan harinya sekitar Jam 11.00 wib kapal kembali bertolak ke Pulau Sebuku Kecil dan sekitar jam 12.00 wib DELI Bin KELATA menyuruh DANIEL GEOVANI Bin MAWARDI untuk membuang jangkar agar kapal berhenti dan DELI Bin KELATA turun menggunakan sampan ke daratan pulau untuk mengambil dugan/ kelapa muda, kemudian datang Petugas kepolisian Polairud Lampung melakukan pengkapan, selanjutnya Terdakwa bersama DAPIT BIN DELI dan DANIEL GEOVANI Bin MAWARDI beserta barang bukti di bawa ke 
Kantor Polairud guna pemeriksaan lebih lanjut. Terdakwa DELI Bin KELATA menerangkan bahwa bahan peledak tersebut miliknya. Terdakwa mengajak DAPIT BIN DELI untuk mempergunakan botol peledak tersebut untuk mencari ikan. Kemudian DELI Bin KELATA meminta DAPIT BIN DELI untuk menjemput DANIEL GEOVANI Bin MAWARDI untuk bersama-sama menggunakan botol yang berisi bahan peledak untuk digunakan mencari ikan di laut. Selanjutnya DAPIT BIN DELI bertugas menghidupkan mesin Kapal dan memegang kemudi sedangkan DANIEL GEOVANI Bin MAWARDI bertugas menarik jangkar dan menguras air di dalam kapal dan DELI Bin KELATA (Alm) bertugas mengambil ikan. Menimbang, bahwa Berdasarkan Hasil Berita Acara Pemeriksaan Laboratorium Forensik Nomor Lab : 09/BHF/2021 Tanggal 04 Februari 2021, yang ditandatangani oleh yang ditandatangani oleh EDHI SURYANTO S.Si., Apt, M.M.,M.T dkk. Bahwa berdasarkan pertimbangan tersebut diatas, Majelis berkesimpulan unsur ini telah terpenuhi. Menimbang, bahwa oleh karena semua unsur dari Pasal 1 Ayat (1) Undang Undang Darurat No. 12 Tahun 1951 tentang Bahan Peledak atau Senjata Api Jo. Pasal 55 Ayat (1) KUHP telah terpenuhi, maka Terdakwa haruslah dinyatakan telah terbukti secara sah dan meyakinkan melakukan tindak pidana sebagaimana didakwakan dalam dakwaan tunggal;

Selama persidangan Majelis tidak menemukan alasan yang dapat menghapuskan pertanggungan jawab terdakwa baik alasan pemaaf maupun pembenar maka terdakwa harus dijatuhkan pidana sesuai dengan rasa keadilan; Dalam perkara ini terhadap Terdakwa telah dikenakan penangkapan dan penahanan yang sah, maka masa penangkapan dan penahanan tersebut harus dikurangkan seluruhnya dari pidana yang dijatuhkan; bahwa oleh karena Terdakwa ditahan dan penahanan terhadap Terdakwa dilandasi alasan yang cukup, maka perlu ditetapkan agar Terdakwa tetap berada dalam tahanan. Tterhadap barang bukti yang diajukan di persidangan untuk selanjutnya dipertimbangkan sebagai berikut: Menimbang, bahwa barang bukti berupa :

- 6 (enam) Botol Besar yang berisis Bahan Peledak jenis Bom Ikan, 10 (Sepuluh) Botol Sedang yang berisi Bahan Peledak jenis Bom Ikan, 1 (satu) kg Serbuk 
Ampo warna Putih, 1 (satu) buah plastik berisi $\pm 1 \mathrm{~kg}$ belerang yang sudah dicampur Cat Bron, 10 (sepuluh) buah Sumbu Ledak / Detonator, 5 (lima) buah potongan Karet Sendal, 13 (Tiga Belas) Buah Korek Api, 2 (dua) buah Potongan Sikat Gigi, 1 (satu) buah Ember Warna Putih. Dirampas untuk dimusnahkan. - 1 (satu) Unit Kapal warna Merah Lis Putih bermesin Dompeng, 1 (satu) Unit Sampan/Perahu Dayung, 1(satu) Unit Kompresor Merk SWAN warna Hijau berikut selang Kompresor warna Kuning, 2 (dua) buah Box Fiber warna Kuning dan Merah Dikembalikan kepada yang berhak / pemiliknya.

Untuk menjatuhkan pidana terhadap Terdakwa, maka perlu dipertimbangkan terlebih dahulu keadaan yang memberatkan dan yang meringankan Terdakwa.

Keadaan yang memberatkan adalah Perbuatan terdakwa meresahkan masyarakat; sedangkan keadaan yang meringankan: Terdakwa bersikap sopan di dalam persidangan; Terdakwa menyesali dan mengaku terus terang perbuatannya; oleh karena Terdakwa dijatuhi pidana maka haruslah dibebani pula untuk membayar biaya perkara.

Memperhatikan, Pasal 1 Ayat (1) Undang Undang Darurat No. 12 Tahun 1951 tentang Bahan Peledak atau Senjata Api Jo. Pasal 55 Ayat (1) KUHP dan Undang-undang Nomor 8 Tahun 1981 tentang Hukum Acara Pidana serta peraturan perundang-undangan lain yang bersangkutan;

\section{MENGADILI:}

1. Menyatakan Terdakwa DELI Bin KELATA (Alm) terbukti secara sah dan meyakinkan bersalah melakukan tindak pidana "Menguasai, Membawa, Mempunyai Persediaan Padanya atau Mempunyai Dalam Miliknya, Menyimpan, Mengangkut, Menyembunyikan, Mempergunakan Bahan Peledak";

2. Menjatuhkan pidana terhadap Terdakwa DELI Bin KELATA (Alm) oleh karena itu dengan pidana penjara selama 9 (sembilan) bulan;

3. Menetapkan masa penangkapan dan penahanan yang telah dijalani terdakwa dikurangkan seluruhnya dari pidana yang dijatuhkan;

4. Menetapkan agar Terdakwa tetap ditahan; 
5. Menetapkan barang bukti berupa : - 6 (enam) Botol Besar yang berisis Bahan Peledak jenis Bom Ikan, 10 (Sepuluh) Botol Sedang yang berisi Bahan Peledak jenis Bom Ikan, 1 (satu) kg Serbuk Ampo warna Putih, 1 (satu) buah plastik berisi $\pm 1 \mathrm{~kg}$ belerang yang sudah dicampur Cat Bron, 10 (sepuluh) buah Sumbu Ledak / Detonator, 5 (lima) buah potongan Karet Sendal, 13 (Tiga Belas) Buah Korek Api, 2 (dua) buah Potongan Sikat Gigi, 1 (satu) buah Ember Warna Putih Dirampas untuk dimusnahkan. - 1 (satu) Unit Kapal warna Merah Lis Putih bermesin Dompeng, 1 (satu) Unit Sampan/Perahu Dayung, 1(satu) Unit Kompresor Merk SWAN warna Hijau berikut selang Kompresor warna Kuning, 2 (dua) buah Box Fiber warna Kuning dan Merah Dikembalikan kepada yang berhak / pemiliknya. 6. Menetapkan agar terdakwa dibebani membayar biaya perkara sejumlah Rp2.000,00 (dua ribu rupiah);

\section{Penutup}

Dalam melakukan aksinya, Terdakwa menggunakan bahan peledak berupa 6 (enam) botol besar dan 4 (empat) buah botol kecil didapat dengan cara membeli sebanyak 4 (empat) kilogram bubuk Ampo kemudian dirakit sedemikian rupa sehingga dapat digunakan untuk mengebom ikan. Penggunaan bahan kimia, bahan biologis, bahan peledak, alat dan/atau cara, dan/atau bangunan yang dapat merugikan dan/atau membahayakan kelestarian sumber daya ikan dan lingkungannya yang tidak saja mematikan ikan secara langsung, tetapi dapat pula membahayakan kesehatan manusia dan merugikan nelayan serta pembudi daya ikan.

Penjatuhan pidana dalam perkara ini tidaklah semata-mata hanya menghukum orang yang bersalah melakukan tindak pidana, akan tetapi juga mempunyai tujuan untuk membina dan mendidik, sehingga dapat kembali hidup dengan wajar ditengah-tengah masyarakat sehingga diharapkan dapat memperbaiki diri di kemudian hari dan menjadi lebih baik di masa yang akan datang, lalu di sisi lainnya agar yang melakukan tindak pidana dapat menginsyafi kesalahannya untuk tidak mengulangi lagi perbuatannya di masa mendatang, oleh karena itu berdasarkan keadaan yang memberatkan dan meringankan terdakwa, maka Hakim 
berpendapat bahwa pidana yang dijatuhkan kepada terdakwa tersebut telah tepat dan setimpal dengan perbuatannya.

\section{Daftar Pustaka}

Ahmad Rifai, 2010, Penemuan Hukum oleh Hakim dalam Perspektif Hukum Progresif, Sinar Grafika, Jakarta, hlm. 19

Haryono Somun, 2014, Tinjauan Kriminologis Penggunaan Bahan Peledak Dalam Penangkapan Ikan Di Desa Kalupapi Kecamatan Bangkurung Kabupaten Bangkep, Jurnal Ilmu Hukum Legal Opinion, Ed. 3, Vol. 2

Kitab Undang-Undang Hukum Pidana

Marpaung, Lintje. Anna., Hartono, Bambang., Rusli, Tami., Erlina, B., \& Pane, Erina, 2008, Kebijakan Pengelolahan Sumbedaya Air dalam Hubungannya dengan Otonomi Daerah (Studi di propinsi Lampung), Jurnal Pranata Hukum, Vol.3, No.2, hlm.1

M. Choirul Anam dan Muhammad Hafiz, 2015, Penanganan Ujaran Kebencian (Hate Speech) dalam Kerangka Hak Asasi Manusia, Remadja Karya, Bandung, hlm. 10

Putusan Pengadilan Negeri Tanjung Karang Nomor 321/Pid.Sus/2021/Pn.Tjk

Rahmawati, D., Siregig, I. K., \& Hasan, Z, 2021, Pertimbangan Hakim Dalam Menjatuhkan Pidana Terhadap Pelaku Tindak Pidana Pembunuhan Berencana, Widya Yuridika Jurnal Hukum, Vol.4, No.1

Suharto, 2011, Limbah Kimia dalam Pencemaran Udara dan Air Edisi Pertama, Andi Offset, Yogyakarta, hlm. 61

Supriadi dan Alimudin, 2001, Hukum Perikanan di Indonesia, Sinar Grafika, Jakarta, hlm. 10

Undang-Undang Dasar Negara Republik Indonesia Tahun 1945 Hasil Amandemen Ke-4

Undang-Undang Nomor 45 Tahun 2009 tentang Perikanan

Undang Undang Darurat No. 12 Tahun 1951 tentang Bahan Peledak atau Senjata Api

Undang-undang Nomor 8 Tahun 1981 tentang Hukum Acara Pidana

Zainab Ompu Jainah, 2012, Penegakan Hukum Dalam Masyarakat, Journal Of Rural And Development, Vol. 3, No. 2 